population in many districts. Reports were recently made of its presence in North Wales at Bettws-y-Coed (Field, Jan. 1943), and in Scotland in the Forestry Commission and deer forest areas of the Highlands and in a cairn in the Grampians (H. M. Batten, Scotsman, Jan. 30, 1943). In Lakeland it has recently been reported from Ennerdale. The polecat is also increasing in the wilder parts of Great Britain. Foxes have increased at an alarming rate in most parts, even where there were no organized hunts as in Lancashire, while in Lakeland, where the Eskdale Hunt killed a record total of sixty foxes in January, there is considerable controversy over organized fox hunts.

The Scottish mountain hare, which inhabits only a few parts of the Pennines at Penistone above Sheffield, has wandered from the Cheviots, where it is plentiful, to inhabit some of the moors on the extreme northern fringe of Cumberland above Gilsland and Bewcastle. The increase of stoats, weasels and badgers is of considerable agricultural value, because rabbits form such a large part of the food of stoats and badgers, and weasels feed mainly on field mice. The increase of foxes is responsible as much as is trapping for the reduction of rabbits, which form the chief food of foxes, but their depredations upon poultry have necessitated a campaign against them.

\section{A Laboratory in Physical Geography}

A DEVELOPMENT in geographical research and teaching is the subject of an article in the Geographical Joumal of November-December by Prof. F. Debenham, in which he describes the laboratory for physical geography which he has planned and equipped at Cambridge, even though the exigencies of the times have necessitated its temporary dismantlement. The object of the laboratory is to study field processes, usually in miniature, under conditions of close observation and control with the view of ascertaining their mechanism, stages and effect. An amazing array of apparatus has been crowded into one room barely $50 \mathrm{ft}$. long by $19 \mathrm{ft}$. broad. In the wave trough, waves are generated by various methods and ingenious devices allow the measurement of period, height, length, etc. Here also beach building with sand and shingle can be studied. The wave tank, on a smaller scale, provides, among other aims, for the study of land forms produced by long-shore drift. An even more ambitious piece of apparatus is the tidal tank in which the difficulties of producing tidal currents seem to have been overcome, and good results are expected. The stream flume or delta tank seems to work well in the study of alluvial deposition, and the stream curve apparatus is to be used for the investigation of water movement in the bed of a stream. Other problems, too, are to be studied, and the whole laboratory is a promising step in the introduction of quantitative methods in the problems of physical geography.

\section{Public Library of South Australia}

The first report of the Public Library of South Australia, which was formed under the Libraries and Institutes Act, I939, creating a Libraries Department under a Libraries Board of South Australia, with a Principal Librarian as administrative head, covers the half-year ending June 1940, and stresses the need for the permanent allocation of sufficient land for the natural growth of such an essential service. The various properties of the Public Library, the Museum and the Art Gallery have now been reallocated, but despite adaptations the accommodation for library work, particularly for staff and for the country lending service, is entirely inadequate. War conditions have not affected adversely the use made of the Library, as is shown by an increase in readers of more than 7,000 during the year, and the Library staff has been taxed to its utmost to provide information regarding all sorts of conditions arising from the War. Financial provision for books is still inadequate and the Board has recommended the establishment of a research department for handling requests for scientific, technical and economic information. For this a more extensive range of periodicals is urgently required. The country lending service has also been called upon for books beyond the limit of its capacity, and its work has grown so rapidly that early exten. sion of accommodation is necessary to provide adequate working space. The Archives Department has reached the limit of its shelving accommodation and offers of many important series of documents, arising from the present extensive pulping of old records, cannot be accepted because of lack of accommodation.

\section{Joints in Submarine Cables}

R. Miller and C. T. Rose contribute an article on this subject in the Engineering Supplement of Siemens Magazine (Oct.-Nov., 1942). In submarine cables particular care has always to be exercised in dealing with the joints, and every endeavour is made to limit their number by manufacturing individual cable lengths as long as possible, consistent with the methods of transport, storage accommodation, etc., available, and the scheme of laying to be adopted. With submarine cable-laying under normal conditions, it is unlikely that more than one sea joint will be necessary, the cable being laid in two parts, one section from each shore termination. This necessitates cutting the cable at a convenient position, buoying the end, and picking up again after the other section has been laid. The joint is then made on the ship and on completion is cast overboard, after due precautions have been taken. The article refers to both communication cables and power cables, the latter for voltages, for example, up to $33 \mathrm{kV}$. In the section on communication cables the authors discuss gutta-percha joints, splicing the sheathing wires, rubber joints, rubber to gutta-percha joints, and paper joints. The section on power cables is confined to those of the impregnated paper-insulated and lead-covered types and describes the making of subaqueous joints, super-tension joints and the handling of the shore ends of the cable. The article is illustrated and séveral photographs are included showing different stages in the operations of laying submarine cables.

\section{Conference of X-Ray Analysis}

THE analysis of substances and the examination of their behaviour by X-ray diffraction methods has become of considerable importance in the war effort. The Institute of Physics is therefore arranging a second conference on the subject to take place in Cambridge during April 9-10. The provisional programme includes a lecture on "Future Developments in X-Ray Crystallography" by Prof. J. D. Bernal, and discussions on "Quantitative Treatment of 